\title{
THE FEATURES OF INNOVATION MANAGEMENT AT UKRAINIAN AND EUROPEAN ENTERPRISES
}

\author{
Yaroslav PANAS 1 \\ National University «Lviv Polytechnic», Ukraine \\ Solomiia TKACH ${ }^{2}$ \\ SI «Institute of Regional Research named after M.I. Dolishniy of the \\ National Academy of Sciences of Ukraine», Ukraine
}

\begin{abstract}
The purpose of the paper is to define peculiarities of innovation management at enterprises in Ukraine and EU countries. Methodology. Based on European Innovation Scoreboard data a comparative assessment of innovation management have done through three aspects: 1) resource capacity, 2) prospects of business entities innovation activity; 3) innovation activity effectiveness. Analyse for Ukraine has done in comparison with average EU data and also with Poland and Germany. Results. In the article, the place of Ukraine in Europe by innovation development has identified. Retrospective changes of innovation development in Ukraine, Poland, Germany and EU during 2008-2015 have analysed. Despite a big gap between Ukraine and EU in terms of resource capacities and innovation activity prospects of business entities, the level of Ukrainian economy effectiveness sin innovation sector stays stable. The authors have defined substantial differences between systems of innovation management at Ukrainian and European enterprises. Taking into consideration strategic priorities of growth areas of Ukraine and also its integration in EU economy, and based on a comparison of data presented in the European Innovation Scoreboard it was possible to single out a range of discrepancies characteristic of innovation activity management system of Ukrainian and European business entities: managers at Ukrainian enterprises prefer to spend on innovations that are not connected with researches and elaborations; in Ukrainian management system there is almost no experience of cooperation with foreign partners within innovation activity sector; in European countries there are more enterprises which introduce innovation but do not develop them themselves; Ukrainian enterprises' managers lack experience in patenting according to the international Patent Cooperation Treaty and in registering trademarks, projects and designs according to the requirements of European Union Intellectual Property Office. Practical implications. The case study results make possible to innovation activity enterprises of Ukraine and European investor, which work in Ukraine, to develop more successful innovative development strategies of enterprises. Value/originality. The study has identified the necessary improvement direction of innovation management system of Ukrainian enterprises in the context of the specific features of innovation sector of the EU economy functioning.
\end{abstract}

Key words: innovation, management, innovation activity effectiveness, resource capacity.

JEL Classification: M10, O30

\section{Introduction}

The question of scientific support of transformation of management system for business innovation activity in post-informational society is strategically significant in the context of knowledge economy development and preparation to applying in business practices artificial intelligence as an element of cognitive technologies, which will underlie the seventh technological paradigm. Under these conditions, there are such urgent issues as carrying out fundamental transformation, diversification and innovation orientation of Ukrainian economy. This aim cannot be reached without quality changes of innovation activity management at industrial enterprises, which constitute a key link in the chain of creating added value.

The efficient management system cannot be created without qualitative assessment of stage and prospects of innovation activity development. In the majority of scientific researches, this issues is considered from the point of view of retrospective approach. However, experience shows that this approach has a range of major drawbacks under the conditions of rapid change of technological paradigms. A considerable amount of gathered and processed retrospective data becomes irrelevant due to the rapid transformation of key factors

\footnotetext{
Corresponding author:

${ }^{1}$ Department of Personnel Management and Administration, National University «Lviv Polytechnic».

E-mail: yarpanas@gmail.com

${ }^{2}$ Sector of Spatial Development, SI «Institute of Regional Research named after M.I. Dolishniy of the National Academy of Sciences of Ukraine».

E-mail: t.solomija@gmail.com
} 
and their influence on results of business activity of an industrial enterprise and its potential competitiveness. Taking into consideration the aforementioned, research of innovation activity management at enterprises in Ukraine should be done based not only on Ukrainian businesses but also with regard to relevant foreign experience and the world's innovation development tendencies in general. The aim of the article is to define peculiarities of innovation activity management at enterprises in Ukraine and EU countries.

\section{The place of Ukraine in Europe by innovation development}

Ukrainian realia of the couple recent years clearly indicate the obvious choice of European course of development. The free-trade zone agreement with EU has come into effect. In 2016 the share of export of goods from Ukraine to EU countries was $37.1 \%$ (by $2.8 \%$ more compared to 2015). The share of export of goods from Ukraine to CIS countries is $16.6 \%$ including 9.9\% to the Russian Federation (State Statistics Service of Ukraine, 2017). In comparison with 2013, the share of export of goods to EU countries increased by $10.6 \%$ and to CIS countries decreased by $18.2 \%$ (Ministry of Economic Development and Trade of Ukraine, 2017). A drastic change of Ukrainian vector of economic cooperation as well as of innovation activity is obvious.

Taking this into account, let us analyse the peculiarities of Ukrainian innovation activity condition, effectiveness, and management in contrast to the performance indicators in EU and neighbouring countries on the basis of data from the European Innovation Scoreboard (EIS) (picture 1). EIS provide a comparative assessment of research and innovation activity in the states and also defines relative strengths and weaknesses of their research and innovation systems according to indicator sets: 1) resource capacity, 2) prospects of business entities innovation activity and 3) innovation activity effectiveness. The EIS index helps the states to assess the areas where they have to channel their efforts in order to increase innovation activity effectiveness (European Innovation Scoreboard 2016).

EIS divides the country into four groups:

1) innovation leaders (according to the list 2015 this country from Switzerland to the Netherlands);

2) strong innovators (Ireland - Slovenia);

3) moderate innovators (Norway - Turkey);

4) modest innovators (Bulgaria - Ukraine).

With the normalized index 0.178 as of 2015 Ukraine takes the last position and obviously belongs to the group of countries with modest innovation capabilities. In comparison with the countries which are innovation leaders, Ukrainian performance indicator is 4.43.6 times lower, with strong innovators - 3.4-2.7 times lower and, accordingly, with moderate innovators - 2.51.5 times lower.

Innovation leaders in this list are mostly the countries from Northern and Central Europe. The majority of the countries from Eastern Europe, which until recently were characterized by a close to Ukrainian structure of the economy, belong to moderate innovators. The

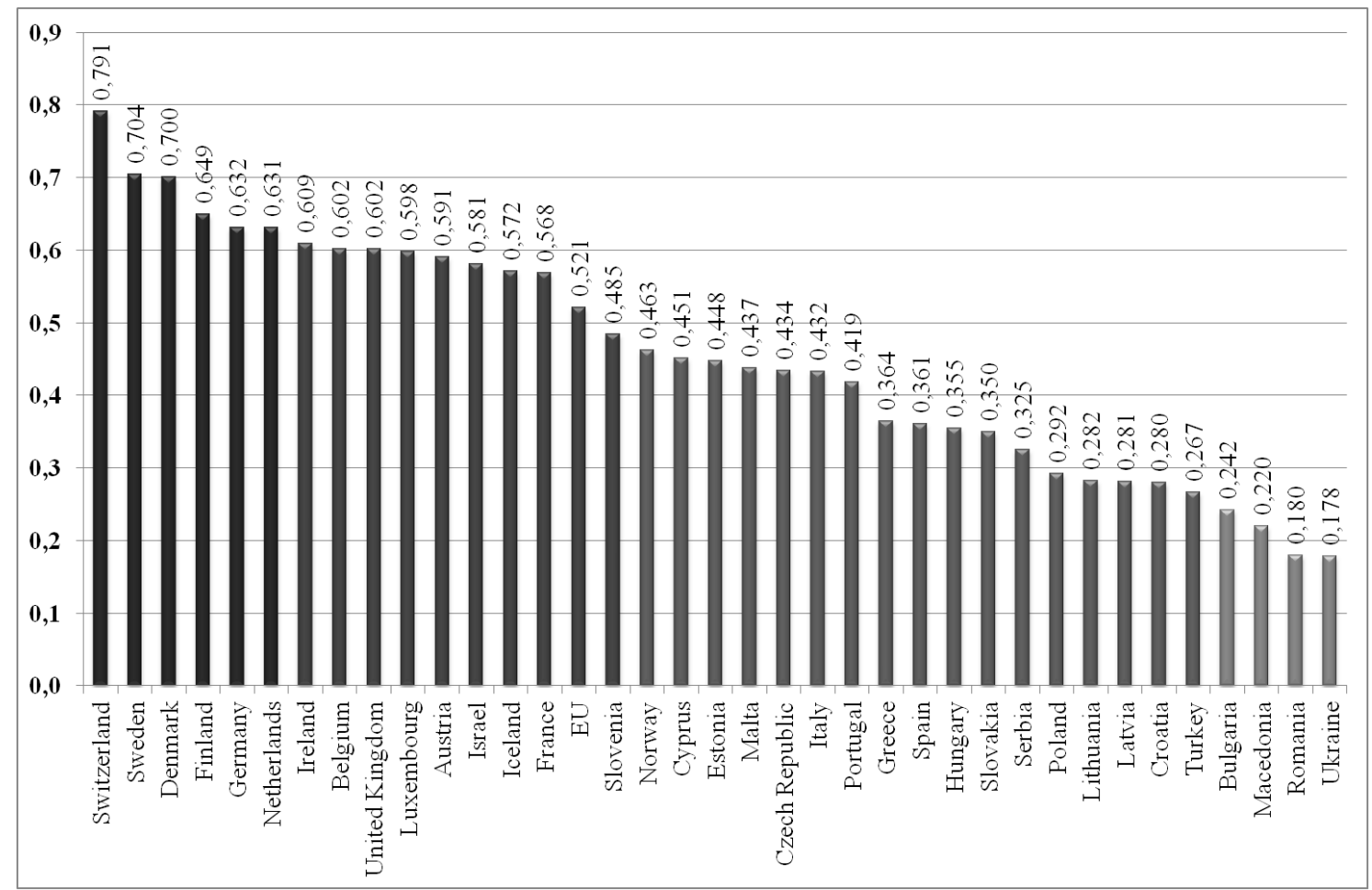

Pic. 1. The Summary Innovation Index by European Innovation Scoreboard in 2015 
only economy of Slovenia is characterized by strong innovation capabilities, which are very close to the average index ofEU countries in general. Many countries of Southern Europe such as Italy, Spain, Portugal and other also have weak innovation capabilities.

\section{Retrospective changes of innovation development in Ukraine, Poland, Germany and EU}

Let us analyse in more detail retrospective changes of the given index for Ukraine in comparison with average EU data and also with Poland and Germany. Comparison with the Polish data will allow analysing condition and effectiveness of conducting innovation activity in Ukraine against the neighbouring country similar in terms of territory and population. Moreover, as far as 20 years ago the practice of conducting business in these two countries was little different. It is also important for the research to assess capabilities of the Ukrainian innovation potential in comparison to the characteristics of the German economy. It is one of the most technologically developed economies in the world. In addition, Germany is a leader in terms of using controlling as a management tool in economic practices of industrial enterprises.

The data in the picture 2 shows that a consolidated index for Ukraine has been quite stable for the last eight years. However, it reached its minimum in 2015. According to the EIS data, innovation development in Ukraine reached its maximum in 2008, 2010 and 2013. Maximum amplitude during the studied period was 0.011 . The level of innovation index in Ukraine is approximately 1.5 time (or is $60-66 \%$ of) smaller than Polish one. During 2008-2015 ranking of both countries did not show any significant changes. Instead, the innovation index of Germany has been steadily going up till 2012 (0.043). In its turn, it decreased by 0.035 during the last three years. With this figure innovation of German economy in 2015 is 3.5 times higher than an analogical Ukrainian one.

In contrast to Ukraine, Poland and Germany where innovation index was stable or slightly decreased, the average EU index displays steady increase during 2008-2015 by 0.026. Such tendency was first and foremost reinforced by resource capacity, prospect innovation potential and results of innovation activity of Malta (+0.112 point), the Netherlands ( +0.082 point), the Great Britain (+0.077 point) and other EU countries. Rather fast pace of increase is shown by Serbia
(+0.099 point $)$ and Turkey (+0.079 point). The most negative tendency in the change of EIS index amplitude belongs to Romania. Its index went down from 2010 to 2015 by 0.084 point. Also more negative than in Ukraine decreasing amplitude of innovation index belongs to Spain (-0.02 point), Croatia (-0.019 point) and some other smaller EU countries.

\section{Resource capacities and innovation activity effectiveness in Ukraine and European countries}

Let us analyse more deeply some particular subindexes for Ukraine, Poland, Germany and EU based on EIS data from 2012-2015, which are displayed in picture 3 .

The data presented indicates that resource capacities of Germany do not differ at all from average data from all the EU countries. However, management approaches they apply provide much better prospects of innovation activity for German business entities and allow achieving a better result from innovation activity of their companies. The respective data from Ukraine and Poland indicates them being considerably behind almost in all group parameters of innovation activity monitoring during the last four years. Only two subindexes of Ukraine and the neighbouring country with respect to human resources and companies' investments can be comparable with EU characteristics during 20122014. In 2015 the sub-index "companies' investments" considerably decreased for Ukraine owing to an almost double drop of innovation expenses share (which are not connected with researches and elaborations) in the total amount of the companies turnover from $0.9 \%$ to $0.5 \%$.

The sub-index of intellectual activity for Ukraine did not undergo major changes during 2012-2015. Its value is measured based on a number of registered patents, trademarks, and design according to the requirements

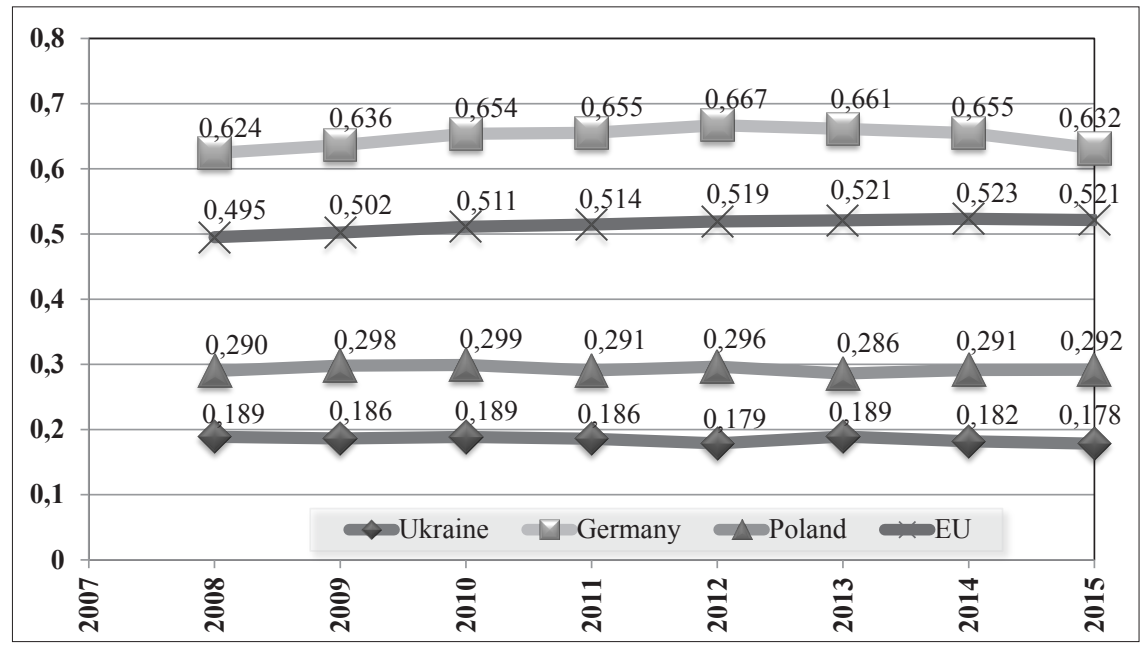

Pic. 2. The Summary Innovation Index for Ukraine, German,

EU by European Innovation Scoreboard in 2008-2015 
Vol. 3, No. 2, 2017
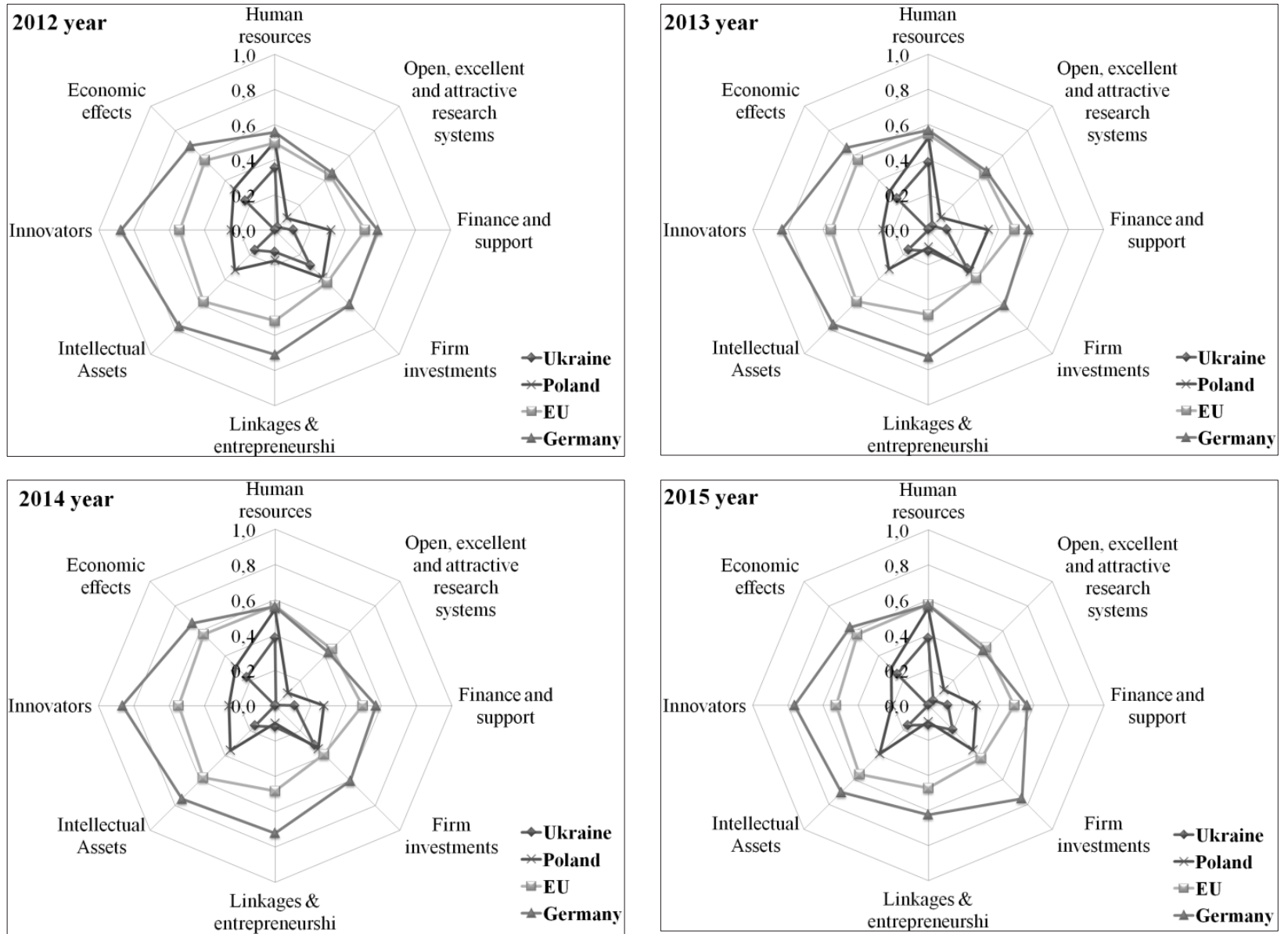

Pic. 3. Sub-indexes for Ukraine, Poland, Germany and EU based on European Innovation Scoreboard data

of The World Intellectual Property Organization (WIPO) and European Union Intellectual Property Office (EUIPO). In 2012-2014 its value was equal to 0.161 . In 2015 due to triple increase (from 0.03 to 0.10 ) of a number of projects and designs registered in accordance with EU requirements it was possible to increase the sub-index "intellectual activity" by 0.002. Disregarding a slight decrease of the respective indicator in EU Ukraine managed to reduce lagging behind Germany by the number of registered projects and designs from 345 times in 2012 to 64 times in 2015. It also worth paying attention to the fact that in 2015 in terms of a number of registered patents according to the international Patent Cooperation Treaty (PCT) Ukraine lags 3.68 times behind Germany only and 2.07 times behind EU.

Despite a big gap between Ukraine and EU in terms of resource capacities and innovation activity prospects of business entities, the level of Ukrainian economy effectiveness sin innovation sector stays stable. In 2015 in terms of "economic effect" sub-index Ukraine lagged behind Poland only by 0.05 , however from the EU countries - by 0.332 and, consequently, from Germany - by 0.379. Moreover, the share of employed staff in a scientific sector (production and services) in the total employment in the economy is not different in all the studied countries. However, the efficiency of their work is different.

The share of knowledge-intensive services export in the total volume of export services in Ukraine has increased by $14 \%$ during the last four years, besides the share of foreign-source license and patent profit in GDP of Ukraine increased by $0.02 \%$. Overall in EU countries the share of knowledge-intensive services export in the total volume of export almost has not changed, and in Germany, it decreased by almost $3 \%$. Opposite tendencies can be observed between Ukraine and EU in terms of the share of medium- and high-tech products in the total volume of products export and in terms of the share of innovation products in business entities turnover. In 2012 the share of medium- and high-tech products in the total volume of products export in Ukraine was 1.4 time smaller than in EU countries, and in 2015 - 1.8 time smaller. The gap between Ukraine and Germany is even bigger - 1.8 time in 2012 and 2.1 times in 2015 . In 2015 the share of innovation products in business entities turnover in Ukraine is almost 4 times smaller than the average one in all EU countries including Germany. 


\section{Substantial differences between systems of innovation management at Ukrainian and foreign enterprises}

Comparison of particular EIS indicators which define innovation activity prospects of business entities and effectiveness of their innovation activity gave the opportunity to single out a range of substantial differences between systems of innovation management at Ukrainian and foreign business entities.

Thus, in Germany and overall in EU countries the share of small and medium enterprises which introduce innovation products and processes (42.44\% in 2015), marketing and organization innovations $(46.23 \%)$ is bigger than the share of respective business entities which develop them (38.6). In its turn, the share of small and medium enterprises in Ukraine, which develop themselves and introduce innovations is approximately during the researched period. However, only $7.4 \%$ of the respective business entities managed to really introduce innovation products and/or processes, and $10.5 \%$ - marketing of organization innovations. Another problem of small and medium Ukrainian enterprises is not being able to establish cooperation in innovation sector with other business entities. In 2012-2015 their share was between $1.5-1.7 \%$, what is by 7-8 times less than in EU countries.

Major differences can be also observed in the management of financial flows for innovation activities at national and European enterprises. According to data indicating technical knowledge creation at enterprises (expenses on researches and developments in the business sector in \% from GDP), Ukraine falls more than 4.5 times behind Germany, and 3 times behind EU. In its turn, the level of investments in equipment and machinery against the background of small and medium Ukrainian enterprises' turnover was almost the same as in Germany and 1.5 time higher than in EU countries. In 2015 Ukraine has started to fall 2.7 times behind Germany in terms of this indicator as a result of double expenses drop and considerable increase of these expenses in the country, which is one of the European and the world's innovation activity leaders.

\section{Conclusion}

The majority of sub-indexes of Germany and EU countries overall, which are displayed in EIS, can serve for Ukraine and Poland only as exemplary strategically characteristics and not as the comparison basis for formulating short- or even medium-term plans of innovation development.

It is possible to drastically change resource capacities for innovation activity of Ukrainian business entities by means of state managerial levers. First of all, mechanism of financing innovation activity has to undergo urgent changes. If the share of state investments in innovation sector in relation to GDP is 2-3 time less in Ukraine than in EU, then the share of venture capital in GDP is $0.002 \%$. According to the data from 2015, it is 24 times less than in Germany and 31 times less than in EU countries in general. These measures do not require considerable financial investments from the state, but they only require research, adaptation, and application of European managerial experience in Ukrainian business practice. Their implementation only needs the change of regulatory framework and methods of regulatory influence.

Thus, taking into consideration strategic priorities of growth areas of Ukraine and also its integration in EU economy, and based on comparison of data presented in the European Innovation Scoreboard it was possible to single out a range of discrepancies characteristic of innovation activity management system of Ukrainian and European business entities:

- managers at Ukrainian enterprises prefer to spend on innovations that are not connected with researches and elaborations;

- in Ukrainian management system there is almost no experience of cooperation with foreign partners within innovation activity sector;

- in European countries there are more enterprises which introduce innovation but do not develop them themselves; - Ukrainian enterprises' managers lack experience in patenting according to the international Patent Cooperation Treaty and in registering trademarks, projects and designs according to the requirements of European Union Intellectual Property Office.

Further studies will be used to study Ukrainian practice of controlling of innovation activities implementation at the industry enterprises.

\section{References:}

European Innovation Scoreboard 2016 (2017). The European Commission. Retvitered from: http://www.knowledgetransferireland.com/About_KTI/Reports-Publications/European-InnovationScoreboard-2016.pdf

Ministry of Economic Development and Trade of Ukraine (2017). Ministry of Economic Development announced the results of export in 2016. Retrieved March 23, 2017, from http://www.me.gov.ua/News/Detail?lang=ukUA\&id=2d7f80e7-7185-4b08-8e87-2e21bb922b9a\&title=MinekonomrozvitkuPidbiloPidsumkiEksport uZa2016-Rik

State Statistics Service of Ukraine (2017). Ukraine's foreign trade of services with countries of the world. Retrieved May 24, 2017, from http://www.ukrstat.gov.ua/ 


\section{Ярослав ПАНАС, Соломия ТКАЧ}

ОСОБЕННОСТИ УПРАВЛЕНИЯ ИННОВАЦИОННОЙ ДЕЯТЕЛЬНОСТЬЮ ОТЕЧЕСТВЕННЫХ И ЕВРОПЕЙСКИХ СУБЪЕКТОВ ХОЗЯЙСТВОВАНИЯ

Аннотация. Целью работы является определение особенностей управления инновационной деятельностью субъектов хозяйствования Украины и стран ЕС. Методика. Основываясь на данных Европейского инновационного табло проведена сравнительная оценка управления инновациями по трем аспектам: 1) ресурсный потенциал, 2) перспективы инновационной деятельности субъектов хозяйствования; 3) эффективность инновационной деятельности. Анализ для Украины сделал по сравнению со средними данными EC, а также с Польшей и Германией. Результаты. В статье показано место Украины в Европе по инновационному развитию. Проанализированы ретроспективные изменения инновационного развития в Украине, Польше, Германии и ЕС в 2008-2015 годах. Несмотря на значительное отставание Украины от стран ЕС в ресурсных возможностях и перспективах инновационной активности субъектов хозяйствования уровень экономической эффективности отечественной экономики в инновационной сфере остается стабильным. Авторы определили существенные различия между системами управления инновационной деятельностью на украинских и европейских предприятиях. Принимая во внимание стратегические приоритеты развития Украины, а также ее интеграцию в экономику ЕС, и на основе сопоставления данных, представленных в Европейском инновационном табло, удалось выделить ряд расхождений, характерных для системы управления инновационной деятельностью украинских и европейских субъектов хозяйствования: руководители украинских предприятий предпочитают проводить инновации, не связанные с исследованиями и разработками; в украинской системе управления практически нет опыта сотрудничества с зарубежными партнерами в сфере инновационной деятельности; в европейских странах существует больше предприятий, которые внедряют инновации, но сами не развивают их; руководители украинских предприятий не имеют опыта патентования в соответствии с международным договором о патентной кооперации и регистрации товарных знаков, проектов и проектов в соответствии с требованиями ведомства интеллектуальной собственности Европейского союза. Практическое значение. Результаты исследований позволяют инновационно активным предприятиям Украины и европейским инвесторам, которые работают в Украине, разрабатывать более успешные стратегии инновационного развития предприятий. Значение/ оригинальность. Результаты исследования определили необходимые направления совершенствования системы управления инновационной деятельностью предприятий Украины с учетом особенностей функционирования инновационной сферы экономики ЕС. 